\title{
BMJ Open Vitamin D status in an Australian patient population: a large retrospective case series focusing on factors associated with variations in serum $25(\mathrm{OH}) \mathrm{D}$
}

To cite: Voo VTF, Stankovich J, O'Brien TJ, et al. Vitamin D status in an Australian patient population: a large retrospective case series focusing on factors associated with variations in serum 25(OH)D. BMJ Open 2020;10:e032567. doi:10.1136/ bmjopen-2019-032567

- Prepublication history for this paper is available online. To view these files, please visit the journal online (http://dx.doi org/10.1136/bmjopen-2019032567).

Received 30 June 2019 Revised 20 December 2019 Accepted 03 February 2020

Check for updates

(C) Author(s) (or their employer(s)) 2020. Re-use permitted under CC BY-NC. No commercial re-use. See rights and permissions. Published by BMJ.

${ }^{1}$ Department of Physiology, University of Melbourne, Parkville, Victoria, Australia 2Department of Neuroscience, Monash Univeristy, Melbourne, Victoria, Australia

${ }^{3}$ Department of Neurology, Royal Melbourne Hospital, Parkville, Victoria, Australia

Correspondence to Dr Mastura Monif; mastura.monif@monash.edu

\section{ABSTRACT}

Objectives To investigate whether sex, age, medical specialty and seasonal variations in serum concentration of 25-hydroxy vitamin $\mathrm{D}(25(\mathrm{OH}) \mathrm{D})$ are evident among an Australian patient population.

Design Retrospective study analysing the results of serum 25(OH)D lab tests and vitamin D supplementation from Royal Melbourne Hospital (RMH) between 2014 and 2017.

Setting Tertiary healthcare centre in Victoria, Australia Participants 30023 patients (inpatient and outpatient) who had their serum 25(OH)D levels measured at $\mathrm{RMH}$ between 2014 and 2017.

Main outcome measures Serum 25(OH)D levels stratified according to patients' sex, age and medical specialty admitted to, as well as the season and year (2014 to 2017) 25(OH)D level was measured.

Results Mean serum 25(OH)D level of study population was $69.9 \mathrm{nmol} / \mathrm{L}$ (95\% Cl 69.5 to 70.2$)$. Only $40.2 \%$ patients in this cohort were sufficient in vitamin $D$ ( $>75 \mathrm{nmol} / \mathrm{L})$. On average, $25(\mathrm{OH}) \mathrm{D}$ levels in male patients were 6.1 units $(95 \% \mathrm{Cl} 5.4$ to 6.9$)$ lower than in females. Linear regression analysis found that $25(\mathrm{OH}) \mathrm{D}$ levels increased by 0.16 unit $(95 \% \mathrm{Cl} 0.14$ to 0.18$)$ for every year increase in age. One-way analysis of variance showed patients from neurology had the highest average $25(\mathrm{OH})$ D level, $76.8 \mathrm{nmol} / \mathrm{L}(95 \% \mathrm{Cl} 74.2$ to 79.3$)$ compared with other medical specialties. Mean 25(OH)D level during winter, $64.9 \mathrm{nmol} / \mathrm{L}(95 \% \mathrm{Cl} 64.2$ to 65.6$)$ was significantly lower compared with other seasons despite supplementation. Average 25(OH)D level measured in $2014,71.5 \mathrm{nmol} / \mathrm{L}$ (95 Cl\% 70.8 to 72.2 ) was significantly higher than levels measured in 2016-2017.

Conclusions There is a sex, age, medical specialty, seasonal and yearly variation in vitamin $D$ status in an Australian patient population. The association between low vitamin D status and winter despite supplementation suggests other interventions are required to boost serum $25(\mathrm{OH}) \mathrm{D}$ levels.

\section{INTRODUCTION}

Interest in the health risks of vitamin D deficiency has skyrocketed over the last 10 years. In Australia, this is reflected in the 128-fold increase in serum vitamin D testing
Strengths and limitations of this study

- To date, this is the largest study of vitamin D status in patients from a tertiary health centre in Australia $(\mathrm{n}=30023)$

- Our findings have contributed to the gap in literature concerning vitamin D status in large Australian cohorts.

- Our findings highlighted the contribution of individual characteristics and seasonal variation of ultraviolet $B$ exposure to vitamin $D$ status, suggesting targeted approaches in interventions to improve vitamin D status.

- Due to being a retrospective study, our study did not include factors such as dietary habits of patients or direct measure of sun exposure.

- The actual quantity of vitamin D supplementation was not recorded, and information on total vitamin D intake of patients was not available.

from 2000 to 2014 and has raised the cost to Medicare from $\$ 1.02$ million in 2000 to over $\$ 140$ million in $2012 .{ }^{1}$ Despite the increased interest in vitamin $\mathrm{D}$, the optimal level that should be targeted remains variable. The consensus from scientific research appears to support serum 25-hydroxy vitamin D $(25(\mathrm{OH})$ D) level sufficiency $>50 \mathrm{nmol} / \mathrm{L}$ and vitamin $\mathrm{D}$ deficiency is generally defined as $<25 \mathrm{nmol} /$ L. ${ }^{2-4}$ It is now widely accepted that adequate vitamin $\mathrm{D}$ levels should be maintained in all life stages, from fetal development to old age. Low vitamin D status has been associated with an increased risk of rickets, osteoporosis, diabetes mellitus, cardiovascular disease, depression, autoimmunity and even pregnancy complications. ${ }^{5-12}$ Low prenatal and early life vitamin D levels may also increase susceptibility to schizophrenia and multiple sclerosis (MS) in later life. ${ }^{13-15}$ In the elderly, higher risk of vitamin D deficiency and lower vitamin $\mathrm{D}$ status have been reported to be associated with increased fall risk. ${ }^{16} 17$ 
Sunlight exposure remains as the major source of vitamin D synthesis. Exposure of the skin to solar ultraviolet B (UVB; 290-315 nm) radiation converts cutaneous 7-dehydrocholesterol to previtamin $\mathrm{D}_{3}$, which in turn becomes vitamin $\mathrm{D}_{3}$. Vitamin $\mathrm{D}_{3}$ is then metabolised to $25(\mathrm{OH}) \mathrm{D}$ in the liver and is subsequently converted to the biologically active form, $1,25(\mathrm{OH})_{2} \mathrm{D}_{3}$ in the kidneys. Vitamin $1,25(\mathrm{OH})_{2} \mathrm{D}_{3}$ plays a major role in calcium and phosphorus regulation, and as a result influences many metabolic pathways and skeletal health. ${ }^{18}$ Since human vitamin $\mathrm{D}$ is largely synthesised in the skin, serum concentration of $25(\mathrm{OH}) \mathrm{D}$ is influenced by seasonal variation of UVB exposure as well as time spent outdoors, the use of sunscreen and clothing. Numerous studies from different countries have shown seasonal variation in vitamin $\mathrm{D}$ concentrations in children, adults and the elderly; the lowest level is found to be at either spring or winter and highest at either autumn or summer. ${ }^{19-24}$ A review on worldwide vitamin D status identified children (especially those with low birth weight), pregnant women and the elderly being at risk of vitamin $\mathrm{D}$ deficiency. ${ }^{25}$ However, regarding gender variation in vitamin D concentration, findings from different studies remain inconsistent; some studies have shown that women have higher serum 25(OH)D levels while others demonstrated to the contrary. ${ }^{22} 2426$

Although variation in vitamin $\mathrm{D}$ levels has been addressed in several studies across different countries and geographical latitude, studies of vitamin D status in Victoria, Australia are lacking. Therefore, this study sought to investigate whether (1) sex, age and seasonal variations in serum concentration of $25(\mathrm{OH}) \mathrm{D}$ are evident among the Victorian tertiary hospital population; (2) certain subgroups of patients are more at risk of vitamin D deficiency and (3) patients with neurological conditions including MS have a lower vitamin D status.

\section{METHODS}

\section{Study population}

This study retrospectively analysed the results of serum $25(\mathrm{OH}) \mathrm{D}$ lab tests of 30023 patients (inpatient and outpatient) at Royal Melbourne Hospital (RMH), Victoria, Australia between 2014 and 2017. The results were obtained from the pathology department of RMH after receiving approval from the Human Research Ethics Committee, RMH. Further, dispensing records of vitamin D supplementation (cholecalciferol $1000 \mathrm{IU}$ or $50000 \mathrm{IU}$ ) were derived from pharmacy records of the same hospital.

\section{Laboratory assay for serum 25(OH)D measurement}

The vitamin D assay used between March 2014 and December 2017 was the Abbott ARCHITECT immunoassay. Assay performance review was conducted on a daily basis (internally) and monthly basis (externally), and if the assay coefficient of variation percentage $(\mathrm{CV} \%)$ drifted $>8 \%$, the protocol was to adjust the issue. From 2014 to 2017 , internal as well as external assay quality assurance and validity measures were performed at multiple levels of vitamin D. The CV\% obtained during this time was $<6 \%$ for the clinically relevant values of serum $25(\mathrm{OH}) \mathrm{D}$. A different assay was used prior to 2014, and hence data prior to 2014 are not included.

\section{Study design}

Currently, there is no complete agreement on the definition of vitamin $\mathrm{D}$ deficiency or the optimal level; we therefore categorised the patients based on the recommendations from the government journal Australian Prescriber. ${ }^{27}$ The patients were classified into four diagnostic categories according to their serum 25(OH)D levels: deficiency (levels $<25 \mathrm{nmol} / \mathrm{L}$ ), insufficiency (levels 25-50 nmol/L), suboptimal (levels $50-75 \mathrm{nmol} / \mathrm{L}$ ) and sufficiency (levels $>75 \mathrm{nmol} / \mathrm{L}$ ). In addition, patients were also stratified according to their sex, age and the medical specialty that each patient was admitted to at the time that their serum $25(\mathrm{OH}) \mathrm{D}$ concentration was measured. Patients below the age of 20 years were excluded from analysis as they represent only $1 \%$ of the study population $(n=379)$, but had the highest rate of vitamin $\mathrm{D}$ deficiency. Moreover, due to the lack of information on the race-ethnicity of the patients, serum $25(\mathrm{OH}) \mathrm{D}$ levels were not stratified according to race-ethnicity. Additionally, because the data collected do not differentiate between patients who received inpatient and outpatient care, a comparison of vitamin D status between these two populations cannot be made. It is also important to note that the word 'admitted' used throughout the paper refers to both inpatients and outpatients. Seasons were determined according to meteorological seasons in Australia: summer (December, January, February), autumn (March, April, May), winter (June, July, August) and spring (September, October, November).

\section{Patient and public involvement}

Due to being a retrospective study, patients were not involved in this research. Patients were not consulted to comment on the study design or interpret the study outcomes. It was difficult to directly involve patients due to data protection restrictions and patient confidentiality. Patients were not invited to contribute to the writing or editing of this document.

\section{Statistical analysis}

The statistical analysis was performed with $\mathrm{R}$ programming (package: dplyr) and Prism 7. For those that had multiple tests available, only the first vitamin D test for each patient between 2014 and 2017 was used. For patients who were prescribed with multiple vitamin D prescriptions, only the ones issued $>14$ days before serum $25(\mathrm{OH}) \mathrm{D}$ was measured were included. This is to ensure that the vitamin $\mathrm{D}$ supplements have had enough time to affect serum $25(\mathrm{OH})$ D levels. $\chi^{2}$ test was used to compare different vitamin $\mathrm{D}$ diagnostic categories, that is, vitamin D-deficient, insufficient, suboptimal and sufficient groups. Student's t-test was used to compare the vitamin 
D status between sex: female versus male. For comparison of vitamin D levels within multiple groups, analysis of variance or one-way analysis of variance (ANOVA) with posthoc test was used, that is, age, medical specialty, seasonal and yearly variabilities in $25(\mathrm{OH}) \mathrm{D}$ concentration. Regression analysis was performed to analyse the relationship between age and vitamin $\mathrm{D}$ status. In addition, multivariable model was used to analyse the relationship between $25(\mathrm{OH})$ D concentration and neurology patients. Data are presented as mean \pm SEM unless specified otherwise.

\section{RESULTS}

Characteristics of the study population are described in table 1. Mean serum 25 $(\mathrm{OH}) \mathrm{D}$ concentration was $69.9 \mathrm{nmol} / \mathrm{L}$ (95\% CI 69.5 to 70.2 ), with average age of 59.6 years (95\% CI 59.4 to 59.8 ) (figure 1 ). The study population comprised of 30023 patients, of whom $62.3 \%$ were females and $37.6 \%$ males. Patients with undefined sex in their medical records were excluded from analysis. Female $(p<0.0001)$, older age $(p<0.0001)$ and summer $(\mathrm{p}<0.0001)$ were associated with higher vitamin $\mathrm{D}$ status. Male patients had significantly lower $25(\mathrm{OH}) \mathrm{D}$ levels compared with females $(\mathrm{p}<0.0001)$. On average, $25(\mathrm{OH}) \mathrm{D}$ levels in male patients were 6.1 units lower than in females (95\% CI 5.4 to 6.9). Patients 20-29 years $(n=3099)$ had the lowest mean vitamin D status $(63.3 \mathrm{nmol} / \mathrm{L})$, while patients $>70$ years $(\mathrm{n}=11225)$ had the highest $(73.2 \mathrm{nmol} / \mathrm{L})$. Regardless, one-way ANOVA showed significant difference in average 25(OH) D concentrations between all age groups $(\mathrm{p}<0.0001)$. Linear regression analysis also found that vitamin $\mathrm{D}$ status increased by 0.16 unit (95\% CI 0.14 to 0.18 ) for every year increase in age. MS can occur at any age, but most commonly affects people between 20 and 40 years with a peak incidence occurring at 30 years of age. ${ }^{28}$ Therefore, age group 20-29 was used as a reference group. Mean serum $25(\mathrm{OH}) \mathrm{D}$ level of patients $\geq 50$ years was significantly higher than patients in the 20-29year age category $(\mathrm{p}<0.0001)$ (figure 2$)$. However, mean $25(\mathrm{OH}) \mathrm{D}$ concentration of neurology patients $(41.7 \%$ have MS) was significantly higher than patients from all other medical specialties (figure 3). Patients admitted to neurology $(76.8 \mathrm{nmol} / \mathrm{L}, 95 \%$ CI 74.2 to 79.3$)$ had the highest average $25(\mathrm{OH}) \mathrm{D}$ level, while patients from nephrology $(64.1 \mathrm{nmol} / \mathrm{L}, 95 \%$ CI 58.5 to 69.7$)$ had the lowest. Regardless, average $25(\mathrm{OH}) \mathrm{D}$ levels between all medical specialties were found to be significantly different $(\mathrm{p}<0.0001)$. The lowest mean 25(OH)D level was found in winter $(64.9 \mathrm{nmol} / \mathrm{L}, 95 \%$ CI 64.2 to 65.6$)$, while the highest level was found in summer $(76.1 \mathrm{nmol} / \mathrm{L}, 95 \%$ CI 74.3 to 77.9 ). Average $25(\mathrm{OH}) \mathrm{D}$ level at winter (Jun-Aug) was significantly lower compared with levels from all other seasons (figure 4). The average $25(\mathrm{OH}) \mathrm{D}$ concentration from tests measured in $2014(71.5 \mathrm{nmol} / \mathrm{L}, 95 \%$ CI 70.8 to 72.2) was significantly higher than levels measured in 2016-2017 ( $<<0.0001)$ (figure 5).
Table 1 Characteristics of the study population $(n=30023)$ and average serum $25(\mathrm{OH}) \mathrm{D}$ levels

\begin{tabular}{lcl}
\hline & N (\%) & $\begin{array}{l}\text { Mean 25(OH)D } \\
\text { (SEM) }\end{array}$ \\
\hline Total population & $30023(100 \%)$ & $69.9(0.19)$ \\
\hline Sex & & \\
\hline Female & $18688(62.3 \%)$ & $72.1(0.25)$ \\
\hline Male & $11302(37.6 \%)$ & $66.0(0.30)$ \\
\hline Age group & & \\
\hline $20-29$ & $3099(10.3 \%)$ & $63.3(0.55)$ \\
\hline $30-39$ & $3721(12.4 \%)$ & $66.3(0.56)$ \\
\hline $40-49$ & $3570(11.9 \%)$ & $66.6(0.57)$ \\
\hline $50-59$ & $4131(13.8 \%)$ & $69.5(0.53)$ \\
\hline $60-69$ & $4277(14.2 \%)$ & $71.7(0.49)$ \\
\hline >70 & $11225(37.4 \%)$ & $73.2(0.31)$ \\
\hline Medical specialty & & \\
\hline AMU & $1690(5.6 \%)$ & $69.0(0.81)$ \\
\hline BOE & $1053(3.5 \%)$ & $71.2(0.92)$ \\
\hline EMER & $1656(5.5 \%)$ & $69.6(0.86)$ \\
\hline ENDO & $1229(4.1 \%)$ & $74.0(0.90)$ \\
\hline GAST & $1574(5.2 \%)$ & $66.9(0.79)$ \\
\hline NEPH & $1261(4.2 \%)$ & $64.1(0.80)$ \\
\hline NEUR & $654(2.2 \%)$ & $76.8(1.66)$ \\
\hline ORTH & $1080(3.6 \%)$ & $67.9(0.89)$ \\
\hline OTHER & $14214(47.3 \%)$ & $68.0(0.27)$ \\
\hline PRIV & $5612(18.7 \%)$ & $75.5(0.47)$ \\
\hline Season of measurement & & \\
\hline Summer (Dec-Feb) & $5588(18.6 \%)$ & $76.1(0.43)$ \\
\hline Autumn (Mar-May) & $8366(27.9 \%)$ & $74.0(0.36)$ \\
\hline Winter (Jun-Aug) & $8320(27.7 \%)$ & $64.9(0.36)$ \\
\hline Spring (Sep-Nov) & $7749(25.8 \%)$ & $66.2(0.37)$ \\
\hline Year of measurement & & \\
\hline 2014 & $8063(26.9 \%)$ & $71.5(0.37)$ \\
\hline 2015 & $7620(25.3 \%)$ & $71.3(0.38)$ \\
\hline 2016 & $7401(24.7 \%)$ & $68.6(0.39)$ \\
\hline Ninformation & $6939(23.1 \%)$ & $67.7(0.39)$ \\
\hline
\end{tabular}

Specialties with $<1000$ patients (except for NEUR) were placed into OTHER for analysis.

AMU, acute medical unit; BOE, breast/oncology/endocrine surgery; EMER, emergency; ENDO, endocrinology; GAST, gastroenterology; NEPH, nephrology; NEUR, neurology; ORTH, orthopaedic; PRIV, private.

\section{Multivariable analysis}

Results of the multivariable regression analysis on $25(\mathrm{OH}) \mathrm{D}$ levels by specialty are described in table 2 . Patients from neurology were found to have the highest 


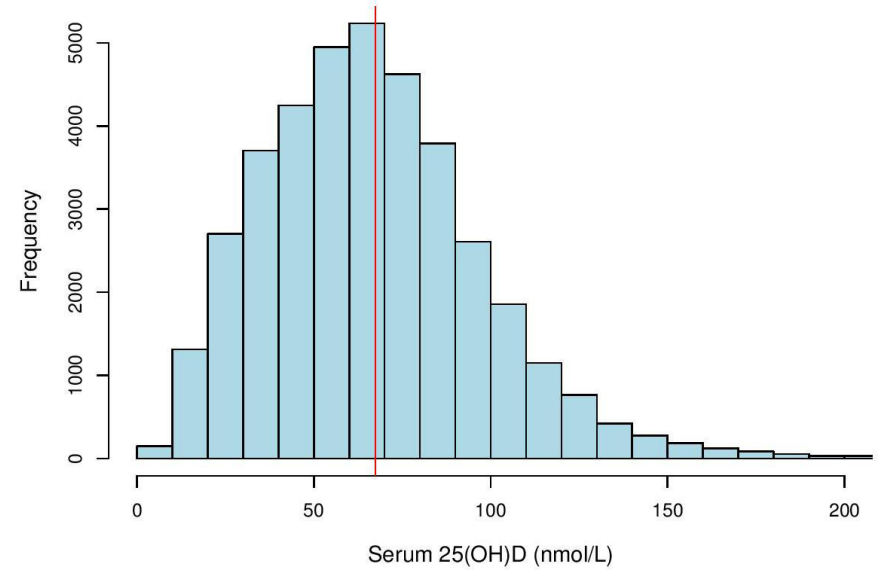

Figure 1 Histogram of serum 25(OH)D distribution in study population $(n=30023)$. Histogram showing distribution of serum 25(OH)D levels (nmol/L) among 30023 patients at Royal Melbourne Hospital, Victoria, Australia between 2014 and 2017. The vertical solid line (in red) is the mean value, $69.9 \pm 0.19 \mathrm{nmol} / \mathrm{L}$.

average 25(OH)D level compared with patients from other specialties, after accounting for sex and age, the season and year that the vitamin $\mathrm{D}$ tests were measured as well as vitamin D supplementation intake.

\section{Vitamin D diagnostic groups}

Characteristics of the study population stratified according to their serum $25(\mathrm{OH}) \mathrm{D}$ levels are described in table 3 . Only $40.2 \%$ patients in this cohort were sufficient in vitamin $\mathrm{D}$, and $55.8 \%$ of patients who were prescribed vitamin D supplementation had sufficient vitamin D levels. The proportion of patients on vitamin $\mathrm{D}$ supplementation varied significantly between various levels of $25(\mathrm{OH}) \mathrm{D}$ concentration $\left(\mathrm{p}<0.0001, \chi^{2}\right.$ test). Although female patients had a higher mean $25(\mathrm{OH}) \mathrm{D}$ concentration than males, only $43.1 \%$ had sufficient $25(\mathrm{OH}) \mathrm{D}$ levels compared with

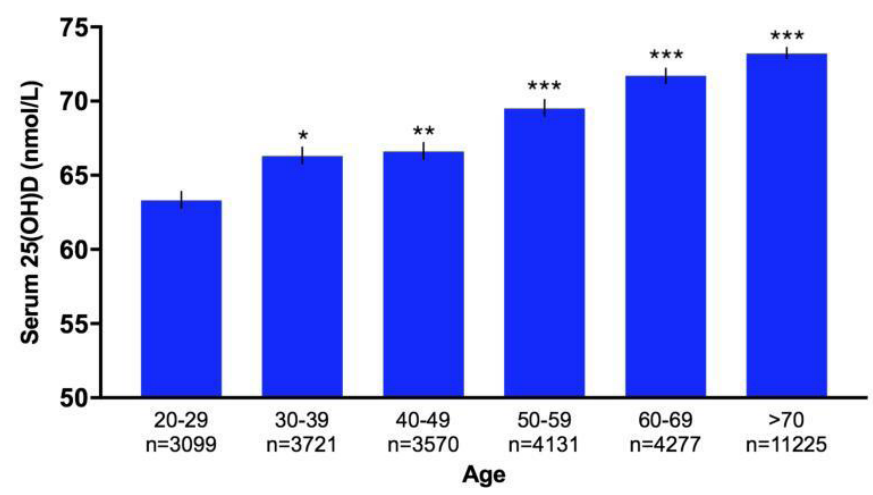

Figure 2 Bar graph of age variation in serum 25(OH)D levels in study population $(n=30023)$. Bar graph showing age variation in serum $25(\mathrm{OH}) \mathrm{D}$ levels (nmol/L) of 30023 patients at Royal Melbourne Hospital, Victoria, Australia between 2014 and 2017. 25(OH)D levels increased with age, and patients $\geq 50$ years had significantly higher mean $25(\mathrm{OH})$ D concentrations compared with patients aged 20-29 years. Error bars represent SEM. Statistical significance of $p$ values: $p<0.05 ;{ }^{*} p<0.01 ;{ }^{* \star} p<0.001 ;{ }^{* \star *} p<0.0001$.

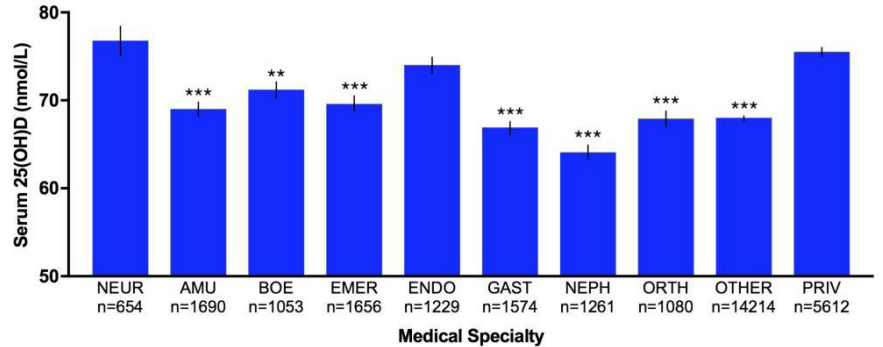

Figure 3 Bar graph of variations in serum 25(OH)D level of patients admitted to various medical specialties $(n=30023)$. Bar graph showing variation in serum 25(OH)D levels (nmol/L) of 30023 patients admitted to all medical specialties at Royal Melbourne Hospital, Victoria, Australia between 2014 and 2017. Specialties with $<1000$ patients (except for NEUR) were placed into OTHER for analysis. Analysis showed the average 25(OH)D levels of patients from all other specialties were significantly lower compared with NEUR except ENDO and PRIV. Error bars represent SEM. Statistical significance of $p$ values: $p<0.05 ;{ }^{*} p<0.01 ;{ }^{* \star} p<0.001 ;{ }^{* \star *} p<0.0001$. AMU, acute medical unit; BOE, breast/oncology/endocrine surgery; EMER, emergency; ENDO, endocrinology; GAST, gastroenterology; NEPH, nephrology; NEUR, neurology; ORTH, orthopaedic; PRIV, private.

$35.5 \%$ of male patients. The age of patients increased with increasing $25(\mathrm{OH}) \mathrm{D}$ levels; the average age $($ mean $\pm \mathrm{SD})$ of patients who had $25(\mathrm{OH}) \mathrm{D}$ levels $>75 \mathrm{nmol} / \mathrm{L}$ was $60.6 \pm 20.8$, while patients who were vitamin $\mathrm{D}$ deficient $(<25 \mathrm{nmol} / \mathrm{L})$ had an average age of 55.6 \pm 22.3 . Although patients from neurology had the highest average $25(\mathrm{OH}) \mathrm{D}$ concentration, only $44.6 \%$ were sufficient in vitamin $\mathrm{D}$ level. As expected, proportion of patients who were vitamin D sufficient were the lowest in winter $(34.0 \%)$ compared with

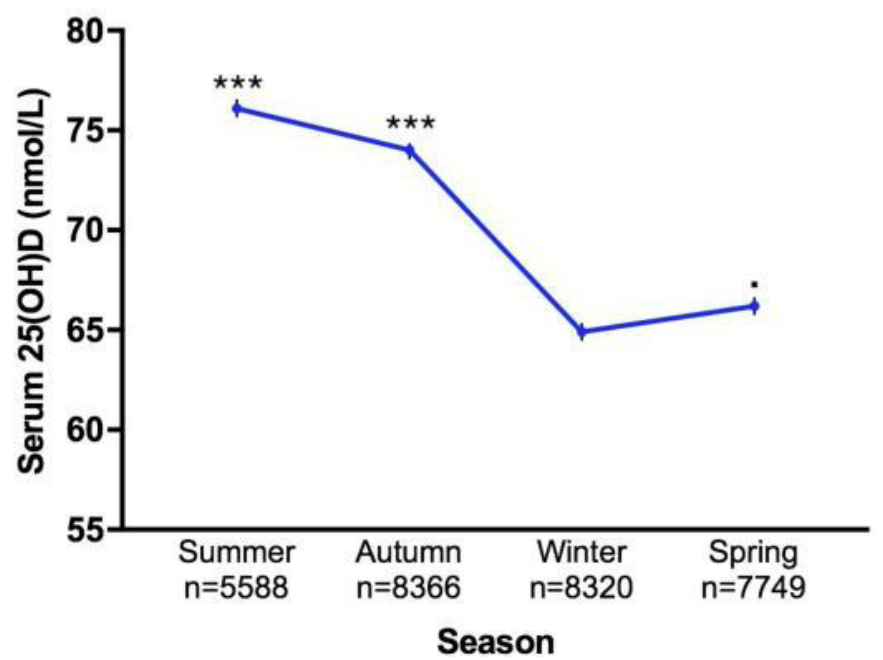

Figure 4 Line graph of seasonal variation in serum $25(\mathrm{OH})$ $D$ levels in study population $(n=30023)$. Line graph showing seasonal variation in serum $25(\mathrm{OH}) \mathrm{D}$ levels $(\mathrm{nmol} / \mathrm{L})$ of 30023 patients at Royal Melbourne Hospital, Victoria, Australia between 2014 and 2017. Analysis showed the average 25(OH)D levels of all other seasons were significantly higher compared with winter. Error bars represent SEM. Statistical significance of $p$ values: $p<0.05 ;{ }^{\star} p<0.01 ;{ }^{* \star} p<0.001$; ${ }^{* \star *} p<0.0001$. 


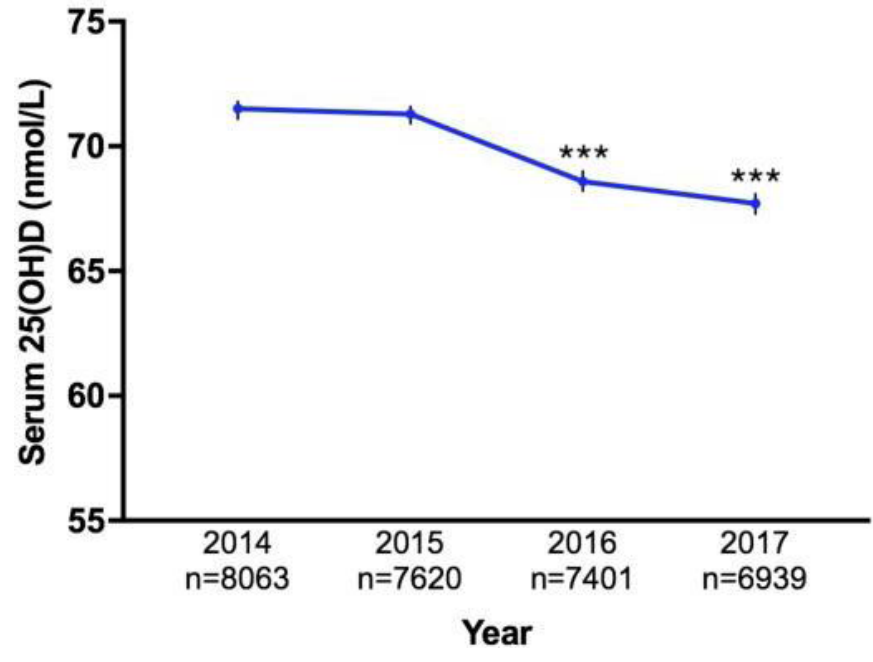

Figure 5 Line graph of yearly variation (2014-2017) in serum $25(\mathrm{OH}) \mathrm{D}$ levels in study population $(n=30023)$. Line graph showing variation in serum $25(\mathrm{OH}) \mathrm{D}$ levels (nmol/L) of 30023 patients measured between 2014 and 2017 at Royal Melbourne Hospital, Victoria, Australia. The mean 25(OH)D level measured in 2014 was significantly higher than levels measured in 2016-2017. Error bars represent SEM. Statistical significance of $p$ values: $p<0.05 ;{ }^{*} p<0.01 ;{ }^{* *} p<0.001$; ${ }^{\star * *} p<0.0001$.

$47.8 \%$ of patients who had their $25(\mathrm{OH}) \mathrm{D}$ level measured in summer. Interestingly, the proportion of patients who had their 25(OH)D levels measured in 2014 were significantly higher $(\mathrm{p}<0.0001)$ in the vitamin $\mathrm{D}$ sufficient group and significantly lower $(\mathrm{p}<0.0001)$ in the vitamin $\mathrm{D}$

Table 2 Results of multivariable linear regression analyses to model serum 25(OH)D levels by specialty, adjusting for sex, age, season, year of measurement and vitamin $D$ supplementation intake

\begin{tabular}{llll}
\hline \multicolumn{5}{c}{} & $\begin{array}{l}\text { Adjusted } \\
\text { difference in } \\
\text { mean 25(OH)D }\end{array}$ & 95\% Cl & P value \\
\hline Medical specialty & & \\
\hline NEUR & Reference & - & - \\
AMU & -12.4 & -15.3 to -9.4 & $<0.0001$ \\
\hline BOE & -9.1 & -12.2 to -5.9 & $<0.0001$ \\
EMER & -11.9 & -14.9 to -9.0 & $<0.0001$ \\
\hline ENDO & -4.8 & -7.9 to -1.8 & 0.0017 \\
GAST & -9.7 & -12.6 to -6.8 & $<0.0001$ \\
NEPH & -14.4 & -17.4 to -11.4 & $<0.0001$ \\
ORTH & -14.3 & -17.4 to -11.1 & $<0.0001$ \\
\hline OTHER & -10.8 & -13.3 to -8.3 & $<0.0001$ \\
\hline PRIV & -1.9 & -4.5 to -0.7 & 0.1565 \\
\hline
\end{tabular}

Specialties with $<1000$ patients (except for NEUR) were placed into OTHER for analysis.

AMU, acute medical unit; BOE, breast/oncology/endocrine surgery; EMER, emergency; ENDO, endocrinology; GAST, gastroenterology; $\mathrm{NEPH}$, nephrology; NEUR, neurology; ORTH, orthopaedic; PRIV, private. deficient group compared with patients between 2015 and 2017 ( $\chi^{2}$ test). $\chi^{2}$ tests also yielded significant differences between the proportion of patients with various levels of vitamin $\mathrm{D}$ insufficiency in the following categories: sex $(p<0.0001)$, age $(p<0.0001)$, medical specialty $(p<0.0001)$, season $(\mathrm{p}<0.0001)$ and year $(\mathrm{p}<0.0001)$.

\section{Vitamin D supplementation}

Characteristics of the study population on vitamin D supplementation are shown in table 4 . A higher proportion of male patients were prescribed with supplementation compared with females. Prescription of vitamin D supplements increased with increasing age. Patients from acute medical unit and nephrology were found to have the highest proportion of patients on supplementation. Unsurprisingly, more patients were prescribed with vitamin D supplements during winter and spring. Interestingly, proportion of patients on vitamin D supplementation increased from 2014 to 2017 annually.

\section{DISCUSSION}

This is the largest study on serum $25(\mathrm{OH}) \mathrm{D}$ levels in a tertiary hospital population in Victoria, Australia ( $\mathrm{n}=30023)$ to date. Our study found sex, age and seasonal variations in serum $25(\mathrm{OH})$ D levels. Patients who were not on vitamin D supplementation were found to have a higher risk of vitamin D deficiency, especially during winter. Moreover, our findings have shown that patients from neurology had a higher mean $25(\mathrm{OH}) \mathrm{D}$ level compared with patients admitted to other medical specialties.

The mean serum 25(OH)D level for all 30023 patients in our study was suboptimal $(69.9 \mathrm{nmol} / \mathrm{L})$. Both female and male patients across all age groups and medical specialties (except for patients admitted to neurology and private hospitals) showed suboptimal serum vitamin D status. Only patients who were on supplementation, and patients admitted to neurology and private hospital were sufficient in vitamin $\mathrm{D}(>75 \mathrm{nmol} / \mathrm{L})$. Moreover, only patients who had their vitamin D levels measured in summer had sufficient vitamin D level compared with other seasons. In the present study, we found that $5.5 \%$ of patients were vitamin $\mathrm{D}$ deficient and only $40.2 \%$ were sufficient in vitamin D. Pharmacy records on vitamin D supplementation correlated to serum $25(\mathrm{OH}) \mathrm{D}$ measured. In the vitamin D sufficient group, $55.8 \%$ of patients were prescribed vitamin D supplements $>14$ days before their serum $25(\mathrm{OH})$ D levels were measured, while only $2.4 \%$ in the vitamin D deficient group were prescribed with supplements. However, this correlation was not reflected in the gender variation found in serum $25(\mathrm{OH}) \mathrm{D}$ levels measured. Females had a higher vitamin $\mathrm{D}$ status compared with males; $43.1 \%$ of females were sufficient in vitamin D while only $35.5 \%$ of male patients were vitamin $\mathrm{D}$ sufficient. According to pharmacy records, $9.9 \%$ of male patients were prescribed with vitamin D supplements, compared with $7.9 \%$ of females. Therefore, females had higher 25(OH)D levels despite less patients being prescribed with supplements. Our findings are in 
Table 3 Characteristics of the study population stratified according to serum 25(OH)D levels

\begin{tabular}{|c|c|c|c|c|c|c|}
\hline & Total N & $\begin{array}{l}\text { Deficiency (<25 } \\
\mathrm{nmol} / \mathrm{L})\end{array}$ & $\begin{array}{l}\text { Insufficiency (25- } \\
50 \mathrm{nmol} / \mathrm{L})\end{array}$ & $\begin{array}{l}\text { Suboptimal } \\
\text { (50-75 nmol/L) }\end{array}$ & $\begin{array}{l}\text { Sufficiency (>75 } \\
\mathrm{nmol} / \mathrm{L})\end{array}$ & $P$ value \\
\hline Total population & 30023 & 1655 (5.5\%) & 6824 (22.7\%) & 9467 (31.5\%) & 12077 (40.2\%) & \\
\hline \multicolumn{7}{|l|}{ Sex } \\
\hline Female & 18688 & $884(4.7 \%)$ & 3920 (21.0\%) & $5836(31.2 \%)$ & 8048 (43.1\%) & $<0.0001$ \\
\hline Male & 11302 & $770(6.8 \%)$ & 2899 (25.7\%) & 3622 (32.0\%) & $4011(35.5 \%)$ & \\
\hline \multicolumn{7}{|l|}{ Age } \\
\hline $20-29$ & 3099 & 217 (7.0\%) & 875 (28.2\%) & 1054 (34.0\%) & 953 (30.8\%) & \\
\hline $30-39$ & 3721 & $236(6.3 \%)$ & 991 (26.6\%) & 1242 (33.4\%) & 1252 (33.7\%) & \\
\hline $40-49$ & 3570 & 227 (6.4\%) & 954 (26.7\%) & 1163 (32.6\%) & $1226(34.3 \%)$ & $<0.0001$ \\
\hline $50-59$ & 4131 & $214(5.2 \%)$ & 995 (24.1\%) & 1320 (32.0\%) & 1602 (38.7\%) & \\
\hline $60-69$ & 4277 & 204 (4.8\%) & $862(20.1 \%)$ & 1354 (31.7\%) & 1857 (43.4\%) & \\
\hline$>70$ & 11225 & 557 (5.0\%) & 2147 (19.1\%) & 3334 (29.7\%) & $5187(46.2 \%)$ & \\
\hline \multicolumn{7}{|l|}{ Medical specialty } \\
\hline AMU & 1690 & $154(9.1 \%)$ & $352(20.8 \%)$ & 480 (28.4\%) & 704 (41.7\%) & \\
\hline BOE & 1053 & 37 (3.5\%) & $212(20.1 \%)$ & 358 (34.0\%) & 446 (42.4\%) & \\
\hline EMER & 1656 & $122(7.4 \%)$ & $392(23.7 \%)$ & $460(27.8 \%)$ & $682(41.2 \%)$ & \\
\hline ENDO & 1229 & 42 (3.4\%) & 221 (18.0\%) & 417 (33.9\%) & 549 (44.7\%) & \\
\hline GAST & 1574 & $76(4.8 \%)$ & $426(27.1 \%)$ & 502 (31.9\%) & $570(36.2 \%)$ & $<0.0001$ \\
\hline NEPH & 1261 & $86(6.8 \%)$ & $336(26.6 \%)$ & 405 (32.1\%) & 434 (34.4\%) & \\
\hline NEUR & 654 & $33(5.0 \%)$ & $120(18.3 \%)$ & 209 (32.0\%) & $292(44.6 \%)$ & \\
\hline ORTH & 1080 & 72 (6.7\%) & 215 (19.9\%) & 376 (34.8\%) & 417 (38.6\%) & \\
\hline OTHER & 14214 & $859(6.0 \%)$ & 3456 (24.3\%) & 4462 (31.4\%) & 5437 (38.3\%) & \\
\hline PRIV & 5612 & $174(3.1 \%)$ & 1094 (19.5\%) & 1798 (32.0\%) & 2546 (45.4\%) & \\
\hline \multicolumn{7}{|l|}{$\begin{array}{l}\text { Season of } \\
\text { measurement }\end{array}$} \\
\hline Summer (Dec-Feb) & 5588 & $168(3.0 \%)$ & $901(16.1 \%)$ & 1847 (33.1\%) & 2672 (47.8\%) & $<0.0001$ \\
\hline Autumn (Mar-May) & 8366 & $266(3.2 \%)$ & 1570 (18.7\%) & 2732 (32.7\%) & 3798 (45.4\%) & \\
\hline Winter (Jun-Aug) & 8320 & 625 (7.5\%) & 2324 (27.9\%) & 2545 (30.6\%) & 2826 (34.0\%) & \\
\hline Spring (Sep-Nov) & 7749 & $596(7.7 \%)$ & $2029(26.2 \%)$ & $2343(30.2 \%)$ & $2781(35.9 \%)$ & \\
\hline \multicolumn{7}{|l|}{ Year of measurement } \\
\hline 2014 & 8063 & 277 (3.4\%) & $1794(22.2 \%)$ & $2662(33.0 \%)$ & $3330(41.3 \%)$ & $<0.0001$ \\
\hline 2015 & 7620 & $310(4.1 \%)$ & 1669 (21.9\%) & 2530 (33.2\%) & 3111 (40.8\%) & \\
\hline 2016 & 7401 & $523(7.1 \%)$ & 1700 (23.0\%) & 2267 (30.6\%) & 2911 (39.3\%) & \\
\hline 2017 & 6939 & 545 (7.9\%) & $1661(23.9 \%)$ & 2008 (28.9\%) & 2725 (39.3\%) & \\
\hline \multicolumn{7}{|l|}{$\begin{array}{l}\text { Vitamin D } \\
\text { supplementation }\end{array}$} \\
\hline Yes & 2588 & $63(2.4 \%)$ & 294 (11.4\%) & $786(30.4 \%)$ & 1445 (55.8\%) & $<0.0001$ \\
\hline No information & 27435 & $1592(5.8 \%)$ & $6530(23.8 \%)$ & 8681 (31.6\%) & $10632(38.8 \%)$ & \\
\hline
\end{tabular}

Specialties with $<1000$ patients (except for NEUR) were placed into OTHER for analysis.

AMU, acute medical unit; BOE, breast/oncology/endocrine surgery; EMER, emergency; ENDO, endocrinology; GAST, gastroenterology;

NEPH, nephrology; NEUR, neurology; ORTH, orthopaedic; PRIV, private.

contrary with several previous studies on determinants of vitamin D status in Australia. ${ }^{29}{ }^{30}$ Cross-sectional studies across Australia showed that overall women had lower serum 25(OH)D levels than men (southeast Queensland, $\mathrm{p}=0.06$; Tasmania, $\mathrm{p}<0.01)^{30}$ and another population-based study demonstrated vitamin D deficiency was more prevalent in women. ${ }^{29}$ The inconsistency of our results with other studies could be due to female patients acquiring vitamin D supplements from other sources, or be a particular characteristic of patients attending a tertiary healthcare centre. 
Table 4 Characteristics of the study population on vitamin D supplementation

\begin{tabular}{lcr}
\hline & $\begin{array}{l}\text { Vitamin D } \\
\text { supplementation+ }\end{array}$ & No information (\%) \\
\hline Sex & & \\
\hline Female & $1468(7.9 \%)$ & $17220(92.1 \%)$ \\
\hline Male & $1120(9.9 \%)$ & $10182(90.1 \%)$ \\
\hline Age group & & \\
\hline $20-29$ & $93(3.0 \%)$ & $3006(97.0 \%)$ \\
\hline $30-39$ & $127(3.4 \%)$ & $3594(96.6 \%)$ \\
\hline $40-49$ & $148(4.1 \%)$ & $3422(95.9 \%)$ \\
\hline $50-59$ & $221(5.3 \%)$ & $3910(94.7 \%)$ \\
\hline $60-69$ & $327(7.6 \%)$ & $3950(92.4 \%)$ \\
\hline$>70$ & $1672(14.9 \%)$ & $9553(85.1 \%)$ \\
\hline Medical specialty & & $1364(80.7 \%)$ \\
\hline AMU & $326(19.3 \%)$ & $1030(97.8 \%)$ \\
\hline BOE & $23(2.2 \%)$ & $1445(87.3 \%)$ \\
\hline EMER & $211(12.7 \%)$ & $1100(89.5 \%)$ \\
\hline ENDO & $129(10.5 \%)$ & $1460(92.8 \%)$ \\
\hline GAST & $114(7.2 \%)$ & $1077(85.4 \%)$ \\
\hline NEPH & $184(14.6 \%)$ & $618(94.5 \%)$ \\
\hline NEUR & $36(5.5 \%)$ & $989(91.6 \%)$ \\
\hline ORTH & $91(8.4 \%)$ & $12792(90.0 \%)$ \\
\hline OTHER & $1422(10.0 \%)$ & \\
\hline PRIV & $52(0.9 \%)$ & $(99.1 \%)$ \\
\hline
\end{tabular}

Season of

measurement

\begin{tabular}{lll}
$\begin{array}{l}\text { Summer (Dec- } \\
\text { Feb) }\end{array}$ & $529(9.5 \%)$ & $5059(90.5 \%)$ \\
$\begin{array}{l}\text { Autumn (Mar- } \\
\text { May) }\end{array}$ & $672(8.0 \%)$ & $7694(92.0 \%)$ \\
\hline $\begin{array}{l}\text { Winter (Jun-Aug) } \\
\text { Spring (Sep-Nov) }\end{array}$ & $697(8.4 \%)$ & $7623(91.6 \%)$ \\
\hline $\begin{array}{l}\text { Year of } \\
\text { measurement }\end{array}$ & $7059(91.1 \%)$ \\
\hline 2014 & $455(5.6 \%)$ & $7608(94.4 \%)$ \\
2015 & $652(8.6 \%)$ & $6968(91.4 \%)$ \\
\hline 2016 & $730(9.9 \%)$ & $6671(90.1 \%)$ \\
2017 & $751(10.8 \%)$ & $6188(89.2 \%)$ \\
\hline
\end{tabular}

Specialties with $<1000$ patients (except for NEUR) were placed into OTHER for analysis.

AMU, acute medical unit; BOE, breast/oncology/endocrine surgery; EMER, emergency; ENDO, endocrinology; GAST, gastroenterology; $\mathrm{NEPH}$, nephrology; NEUR, neurology; ORTH, orthopaedic; PRIV, private.

Contrary to previous studies, ${ }^{31-33}$ we found that $25(\mathrm{OH}) \mathrm{D}$ level increased with increasing age. Vitamin D supplementation could have also contributed to this finding. Serum $25(\mathrm{OH}) \mathrm{D}$ levels were shown to increase with increasing age, but older patients were found to be more likely to be prescribed with vitamin D supplementation (table 4), likely resulting in higher serum $25(\mathrm{OH})$
D measured. This could explain the contradiction of our findings to data demonstrating higher prevalence of vitamin $\mathrm{D}$ deficiency with increasing age in both men and women, ${ }^{31-33}$ which did not take into account supplementation. Contrary to previous studies that demonstrated the association of vitamin D deficiency and neurological disorders such as Parkinson's disease, Alzheimer's disease, MS and epilepsy, ${ }^{34-38}$ our data showed that patients admitted to the neurology specialty had the highest mean $25(\mathrm{OH}) \mathrm{D}$ level compared with patients from all other specialties. Pharmacy records showed that only $5.5 \%$ of patients from neurology were prescribed with vitamin D supplementation, which was on the lower end compared with other specialties (table 4). $41.7 \%$ of neurology patients from our data were diagnosed with MS. Given the numerous literature on the role of vitamin D in MS, low serum vitamin D status is associated with increased susceptibility to MS and worse disease progression, ${ }^{39-46}$ it is conceivable that some patients with MS could have acquired vitamin D supplementation from other sources, and total vitamin $\mathrm{D}$ intake was not recorded. Moreover, patients with other neurological conditions (beside MS) could have also acquired vitamin D supplementation that was not recorded in the prescription records, resulting in higher serum $25(\mathrm{OH}) \mathrm{D}$ measured. ${ }^{47-50}$ This could help explain the contradiction of our results to other findings regarding vitamin $\mathrm{D}$ status of patients with neurological disorders. Our findings also showed that patients admitted to private hospitals had the second highest mean $25(\mathrm{OH}) \mathrm{D}$ level. As patients from private hospitals are a heterogeneous group and comprised of patients with a variety of medical conditions, it is difficult to elucidate specific factors that could have contributed to the higher $25(\mathrm{OH}) \mathrm{D}$ levels measured. One of the possible explanations for this finding could be that patients from private hospitals are presumably more health literate and hence are more likely to use supplementations. Moreover, our results showed that patients admitted to endocrinology had a higher mean $25(\mathrm{OH})$ D level compared with patients from other specialties (except neurology and private hospitals). Most patients admitted to endocrinology at RMH were treated for osteoporosis. Given the numerous literature on vitamin $\mathrm{D}$ and bone health, ${ }^{51-53}$ these patients are commonly prescribed with vitamin $\mathrm{D}$ and calcium supplementation as part of their treatment. A study on 68 residential aged care facilities in Australia ( $\mathrm{n}=9094)$ in 2014-2017 found that $60 \%$ of the residents consistently use vitamin D supplementation. ${ }^{54}$ Hence, it is unsurprising that the mean serum $25(\mathrm{OH}) \mathrm{D}$ level for endocrinology was higher compared with other medical specialties in our study. Our findings also showed that patients admitted to nephrology had the lowest mean serum 25(OH)D level compared with patients from other specialties. The majority of patients from nephrology at RMH were treated for chronic kidney disease (CKD). Vitamin D levels are generally low in these patients, as CKD is 
associated with low levels of vitamin D, especially in patients with end-stage renal disease and kidney transplant recipient. ${ }^{55-59}$ Our findings are consistent with results from previous studies that demonstrated the association between low vitamin $\mathrm{D}$ levels and CKD.

Seasonal variation in serum $25(\mathrm{OH}) \mathrm{D}$ concentration has been addressed in several prior studies. ${ }^{60-62}$ Our results are in agreement with findings of previous studies that demonstrated lower vitamin D status during winter and higher levels during summer months. In a population-based study of 27203 women ( $\geq 55$ years) in Geelong (southeastern Australia), serum 25(OH)D was found to peak in summer and dip in winter $(\mathrm{p}<0.001)$, which is consistent with our results. ${ }^{61}$ Interestingly, despite the fact that more patients were prescribed vitamin D supplementation during winter $(n=697)$ compared with summer $(\mathrm{n}=529)$, serum $25(\mathrm{OH}) \mathrm{D}$ levels remained lower during winter, emphasising the role of seasonal variation of UVB exposure on vitamin D status regardless of supplementation. Notably, serum $25(\mathrm{OH}) \mathrm{D}$ status was significantly higher in 2014 compared with 2016-2017. This is contradictory to the rising trend in vitamin $\mathrm{D}$ status for the past two decades. ${ }^{63}$ Moreover, pharmacy records showed a rise in prescription of vitamin D supplements every year from 2014 to 2017 (table 4), particularly between 2014 and 2015. In 2014, only $5.6 \%$ of patients were prescribed vitamin D supplements compared to $8.6 \%$ in 2015 . One of the possible explanations for this contradiction is the increasing prevalence of obesity in Australia. According to the Australian Bureau of Statistics, in 2017-2018, $67.0 \%$ of Australian adults were overweight and obese, an increase from $63.4 \%$ in $2014-2015 .{ }^{64}$ Current literature shows a consistent association between obesity and low vitamin D concentrations as well as lower vitamin D supplementation intake. ${ }^{6566}$ Possible mechanisms for lower serum vitamin $\mathrm{D}$ status in obese individuals have been proposed, ${ }^{6768}$ and given the growing literature on the association between obesity and low vitamin D concentrations, it would be interesting to include the body mass index of patients to elucidate this possible association.

\section{Limitations}

Our study had a number of limitations. First, this study was carried out retrospectively and factors such as dietary habits of patients or direct measure of sun exposure were not included. Second, there is no consensus on the definition of the clinical terms vitamin D 'deficiency', 'insufficiency', 'suboptimal' and 'sufficiency' as well as the desirable levels of serum $25(\mathrm{OH}) \mathrm{D}$. Third, since vitamin D supplementation data was derived from pharmacy dispensing records at RMH, it cannot be excluded that some patients might elect to purchase vitamin D supplements at other sources such as the supermarket, health food stores or online. It is also important to note that because vitamin $\mathrm{D}$ supplementation does not require a prescription, vitamin D intake of some patients might not be included in the dispensing records. Fourth, in the supplementation data, the actual quantity of supplement (ie, units of vitamin D dispensed) was not recorded. Fifth, because the data collected do not differentiate between patients who received inpatient and outpatient care, a comparison of vitamin D status between these two populations cannot be made. Sixth, due to the lack of information on the race-ethnicity of the patients, serum $25(\mathrm{OH})$ D levels were not stratified according to race-ethnicity. Seventh, the patient population presented here, although quite large, may not be reflective of the general population (general community) as our patients were all from a tertiary hospital setting and likely with medical comorbidities and potentially also with increased rates of vitamin D prescription.

\section{CONCLUSION}

This is the largest study of vitamin D status in patients from a tertiary health centre in Australia to date. The findings reveal that there are sex, age, medical specialty and seasonal variations in serum concentration of $25(\mathrm{OH}) \mathrm{D}$ in an Australian tertiary hospital population. Based on our findings, patients who were not on vitamin D supplementation were at risk of vitamin D deficiency, especially during winter. Our findings showing female gender, older age and neurology patients having higher $25(\mathrm{OH}) \mathrm{D}$ levels are contrary to those previous reports globally. Our study also reveals that despite the role of supplementation, serum $25(\mathrm{OH}) \mathrm{D}$ remained the lowest during winter, highlighting the need of other interventions to boost vitamin D status during winter. Further research is warranted to establish the role of vitamin $\mathrm{D}$ in health and disease state as well as the variations in individual characteristics, seasonal and geographic locations that contribute to the total vitamin D levels. Specifically, given the association between vitamin D and immune-mediated diseases such as MS, understanding the role of this key vitamin would help delineate potential therapeutic approaches in combatting these diseases.

Acknowledgements We would like to acknowledge Maria Bisignano, research support coordinator at Melbourne Health Shared Pathology Service for extracting the results of serum 25(OH)D lab tests from Royal Melbourne Hospital pathology services. We would also like to thank Karen Honson, pharmacist at Royal Melbourne Hospital for extracting the supplementation data from the prescription records.

Contributors Conception and design of study: MM, HB, VTFV, JS, TO'B. Acquisition of data: MM, VTFV. Analysis and/or interpretation of data: JS, VTFV, MM, HB. Drafting the manuscript: VTFV. Revising the manuscript critically: VTFV, MM, SJ, TO'B. All authors contributed to refinement of the study protocol and approved the final manuscript.

Funding This research received no specific grants from any funding agency in the public, commercial or not-for-profit sectors.

Disclaimer The authors have not declared a specific grant for this research from any funding agency in the public, commercial or not-for-profit sectors.

Competing interests None declared.

Patient consent for publication Not required.

Ethics approval The ethics of this research was approved by Melbourne Health ethics committee (number/ID of approval QA2018084) and is done in accordance 
to the World Medical Association Declaration of Helsinki. Patient data and medical records extracted was deidentified and coded without identifiers.

Provenance and peer review Not commissioned; externally peer reviewed.

Data availability statement № data are available. All data are reported in the manuscript itself.

Open access This is an open access article distributed in accordance with the Creative Commons Attribution Non Commercial (CC BY-NC 4.0) license, which permits others to distribute, remix, adapt, build upon this work non-commercially, and license their derivative works on different terms, provided the original work is properly cited, appropriate credit is given, any changes made indicated, and the use is non-commercial. See: http://creativecommons.org/licenses/by-nc/4.0/.

Author note All persons who meet authorship criteria are listed as authors, and all authors certify that they have participated sufficiently in the work to take public responsibility for the content, including participation in the concept, design, analysis, writing or revision of the manuscript. Furthermore, each author certifies that this material or similar material has not been and will not be submitted to or published in any other publication before its appearance in the British Medical Journal (BMJ).

\section{ORCID iD}

Mastura Monif http://orcid.org/0000-0001-6404-9768

\section{REFERENCES}

1 Medicare Australia. Medicare Australia statistics. Available: www. medicareaustralia.gov.au [Accessed 11 Feb 2019].

2 Sahota O. Understanding vitamin D deficiency. Age Ageing 2014:43:589-91.

3 Ross AC, Manson JE, Abrams SA, et al. The 2011 report on dietary reference intakes for calcium and vitamin $D$ from the Institute of medicine: what clinicians need to know. J Clin Endocrinol Metab 2011;96:53-8.

4 Rizzoli R, Boonen S, Brandi M-L, et al. Vitamin D supplementation in elderly or postmenopausal women: a 2013 update of the 2008 recommendations from the European Society for clinical and economic aspects of osteoporosis and osteoarthritis (ESCEO). Curr Med Res Opin 2013;29:305-13.

5 Issa CM. Vitamin D and type 2 diabetes mellitus. Adv Exp Med Biol 2017:996:193-205.

6 Berridge MJ. Vitamin D deficiency and diabetes. Biochem J 2017;474:1321-32

7 Podzolkov VI, Pokrovskaya AE, Panasenko Ol, et al. Vitamin D deficiency and cardiovascular pathology. Ter Arkh 2018;90:144-50.

8 Anglin RES, Samaan Z, Walter SD, et al. Vitamin D deficiency and depression in adults: systematic review and meta-analysis. $\mathrm{Br} J$ Psychiatry 2013;202:100-7.

9 Woo YS, Kim S, Jeong J-H, et al. Vitamin D deficiency/insufficiency among inpatients with depressive symptoms. Clin Psychopharmacol Neurosci 2019;17:121-4.

10 Komisarenko YI, Bobryk MI. Vitamin D deficiency and immune disorders in combined endocrine pathology. Front Endocrinol 2018;9:600.

11 Sharif K, Sharif Y, Watad A, et al. Vitamin D, autoimmunity and recurrent pregnancy loss: more than an association. Am J Reprod Immunol 2018;80:e12991.

12 Bozdag H, Akdeniz E. Does severe vitamin D deficiency impact obstetric outcomes in pregnant women with thyroid autoimmunity? J Matern Fetal Neonatal Med 2018;122:1-11.

13 Balbuena LD, Middleton RM, Tuite-Dalton K, et al. Sunshine, sea, and season of birth: MS incidence in Wales. PLoS One 2016;11:e0155181.

14 Dobson R, Giovannoni G, Ramagopalan S. The month of birth effect in multiple sclerosis: systematic review, meta-analysis and effect of latitude. J Neurol Neurosurg Psychiatry 2013;84:427-32.

15 Eyles DW, Trzaskowski M, Vinkhuyzen AAE, et al. The association between neonatal vitamin D status and risk of schizophrenia. Sci Rep 2018;8:17692.

16 Boettger SF, Angersbach B, Klimek CN, et al. Prevalence and predictors of vitamin D-deficiency in frail older hospitalized patients. BMC Geriatr 2018;18:219.

17 Uusi-Rasi K, Patil R, Karinkanta S, et al. Serum 25-hydroxyvitamin $\mathrm{D}$ levels and incident falls in older women. Osteoporos Int 2019;30:93-101.

18 Wacker M, Holick MF. Sunlight and vitamin D: a global perspective for health. Dermatoendocrinol 2013;5:51-108.
19 Al Zarooni AAR, Al Marzouqi FI, Al Darmaki SH, et al. Prevalence of vitamin $D$ deficiency and associated comorbidities among abu dhabi Emirates population. BMC Res Notes 2019;12:503.

20 Bhattoa HP, Nagy E, More C, et al. Prevalence and seasonal variation of hypovitaminosis $\mathrm{D}$ and its relationship to bone metabolism in healthy Hungarian men over 50 years of age: the HunMen Study. Osteoporos Int 2013;24:179-86.

$21 \mathrm{Gu}$ Y, Zhu Z, Luan X, et al. Vitamin D status and its association with season, depression in stroke. Neurosci Lett 2019;690:99-105.

22 Hansen L, Tjønneland A, Køster B, et al. Vitamin D status and seasonal variation among Danish children and adults: a descriptive study. Nutrients 2018;10:1801.

23 Niculescu DA, Capatina CAM, Dusceac R, et al. Seasonal variation of serum vitamin D levels in Romania. Arch Osteoporos 2017;12:113.

24 Touvier M, Deschasaux M, Montourcy M, et al. Determinants of vitamin D status in Caucasian adults: influence of sun exposure, dietary intake, sociodemographic, lifestyle, anthropometric, and genetic factors. J Invest Dermatol 2015;135:378-88.

25 van Schoor NM, Lips P. Worldwide vitamin D status. Best Pract Res Clin Endocrinol Metab 2011;25:671-80.

26 Lips P. Worldwide status of vitamin D nutrition. J Steroid Biochem Mol Biol 2010;121:297-300.

27 Joshi D, Center JR, Eisman JA. Vitamin D deficiency in adults. Aust Prescr 2010;33:103-6.

28 Milo R, Kahana E. Multiple sclerosis: geoepidemiology, genetics and the environment. Autoimmun Rev 2010;9:A387-94.

29 Daly RM, Gagnon C, Lu ZX, et al. Prevalence of vitamin D deficiency and its determinants in Australian adults aged 25 years and older: a national, population-based study. Clin Endocrinol 2012;77:26-35.

30 van der Mei IAF, Ponsonby A-L, Engelsen O, et al. The high prevalence of vitamin D insufficiency across Australian populations is only partly explained by season and latitude. Environ Health Perspect 2007;115:1132-9.

31 Ardawi M-SM, Qari MH, Rouzi AA, et al. Vitamin D status in relation to obesity, bone mineral density, bone turnover markers and vitamin $D$ receptor genotypes in healthy Saudi pre- and postmenopausal women. Osteoporos Int 2011;22:463-75

32 Chen J, Yun C, He Y, et al. Vitamin D status among the elderly Chinese population: a cross-sectional analysis of the 2010 2013 China national nutrition and health survey (CNNHS). Nutr J 2017; 16:3.

33 Sadat-Ali M, Al Elq AH, Al-Turki HA, et al. Influence of vitamin D levels on bone mineral density and osteoporosis. Ann Saudi Med 2011;31:602-8

34 Annweiler C, Schott A-M, Berrut G, et al. Vitamin D and ageing: neurological issues. Neuropsychobiology 2010;62:139-50.

35 Littlejohns TJ, Henley WE, Lang IA, et al. Vitamin D and the risk of dementia and Alzheimer disease. Neurology 2014;83:920-8.

36 Knekt $\mathrm{P}$, Kilkkinen $\mathrm{A}$, Rissanen $\mathrm{H}$, et al. Serum vitamin $\mathrm{D}$ and the risk of Parkinson disease. Arch Neurol 2010;67:808-11.

37 Holló A, Clemens Z, Lakatos P. Epilepsy and vitamin D. Int J Neurosci 2014;124:387-93.

38 Mazdeh M, Zamani M, Eftekharian MM, et al. Expression analysis of vitamin D receptor-associated IncRNAs in epileptic patients. Metab Brain Dis 2019;34:1457-65.

39 Munger KL, Zhang SM, O'Reilly E, et al. Vitamin D intake and incidence of multiple sclerosis. Neurology 2004;62:60-5.

40 Ramagopalan SV, Maugeri NJ, Handunnetthi L, et al. Expression of the multiple sclerosis-associated MHC class II allele HLA-DRB1*1501 is regulated by vitamin D. PLoS Genet 2009;5:e1000369.

41 van der Mei IAF, Ponsonby A-L, Dwyer T, et al. Vitamin D levels in people with multiple sclerosis and community controls in Tasmania, Australia. J Neurol 2007;254:581.

42 Lucas RM, Ponsonby A-L, Dear K, et al. Sun exposure and vitamin $\mathrm{D}$ are independent risk factors for CNS demyelination. Neurology 2011;76:540-8

43 Mokry LE, Ross S, Ahmad OS, et al. Vitamin D and risk of multiple sclerosis: a Mendelian randomization study. PLoS Med 2015;12:e1001866

44 Rhead B, Bäärnhielm M, Gianfrancesco M, et al. Mendelian randomization shows a causal effect of low vitamin $D$ on multiple sclerosis risk. Neurol Genet 2016;2:e97.

45 Zamzam D, Foad M, Swelam M, et al. Vitamin D and body mass index in Egyptian multiple sclerosis patients. Mult Scler Relat Disord 2019;28:313-6.

46 Voo VTF, O'Brien T, Butzkueven $\mathrm{H}$, et al. The role of vitamin D and P2X7R in multiple sclerosis. J Neuroimmunol 2019;330:159-69.

47 Suzuki M, Yoshioka M, Hashimoto M, et al. Randomized, doubleblind, placebo-controlled trial of vitamin D supplementation in Parkinson disease. Am J Clin Nutr 2013;97:1004-13. 
48 Taghizadeh M, Talaei SA, Djazayeri A, et al. Vitamin D supplementation restores suppressed synaptic plasticity in Alzheimer's disease. Nutr Neurosci 2014;17:172-7.

49 Gangwar AK, Rawat A, Tiwari S, et al. Role of vitamin-D in the prevention and treatment of Alzheimer's disease. Indian J Physiol Pharmacol 2015;59:94-9.

50 Al-Nimer MS. The benefit of prescribing vitamin D as add on therapy on the electrocardiographic changes in epileptic patients. Curr Clin Pharmacol 2018;13:40-4.

51 Hill TR, Verlaan S, Biesheuvel E, et al. A vitamin D, calcium and Leucine-Enriched whey protein nutritional supplement improves measures of bone health in sarcopenic Non-Malnourished older adults: the provide study. Calcif Tissue Int 2019;105:383-91.

52 Thiagarajan NR, Kumar CGD, Sahoo J, et al. Effect of vitamin D and calcium supplementation on bone mineral content in children with thalassemia. Indian Pediatr 2019;56:307-10.

53 Weaver CM, Alexander DD, Boushey CJ, et al. Calcium plus vitamin D supplementation and risk of fractures: an updated meta-analysis from the National osteoporosis Foundation. Osteoporos Int 2016;27:367-76.

54 Lind KE, Jorgensen ML, Gray LC, et al. Anti-Osteoporosis medication use in a high Fracture-Risk population: contemporary trends in Australian residential aged care facilities. Health Serv Insights 2019;12:117863291985211.

55 Capelli I, Cianciolo G, Gasperoni L, et al. Nutritional vitamin D in CKD: should we measure? should we treat? Clin Chim Acta 2020;501:186-97.

56 González EA, Sachdeva A, Oliver DA, et al. Vitamin D insufficiency and deficiency in chronic kidney disease. A single center observational study. Am J Nephrol 2004;24:503-10.

57 Thorsen IS, Bleskestad IH, Åsberg A, et al. Vitamin D as a risk factor for patient survival after kidney transplantation: a prospective observational cohort study. Clin Transplant 2019;33:e13517.
58 Timalsina S, Sigdel MR, Baniya S, et al. Status of vitamin D and parameters of calcium homeostasis in renal transplant recipients in Nepal: a cross sectional study. BMC Nephrol 2018;19:290.

59 Wu C-C, Liao M-T, Hsiao P-J, et al. Antiproteinuria effect of calcitrio in patients with chronic kidney disease and vitamin $D$ deficiency: a randomized controlled study. J Ren Nutr 2019. doi:10.1053/j. jrn.2019.09.001. [Epub ahead of print: 05 Nov 2019].

60 Levis S, Gomez A, Jimenez CMa F, Roos BA, et al. Vitamin $D$ deficiency and seasonal variation in an adult South Florida population. J Clin Endocrinol Metab 2005;90:1557-62.

61 Pasco JA, Henry MJ, Kotowicz MA, et al. Seasonal periodicity of serum vitamin $D$ and parathyroid hormone, bone resorption, and fractures: the Geelong osteoporosis study. J Bone Miner Res 2004;19:752-8.

62 Rucker D, Allan JA, Fick GH, et al. Vitamin D insufficiency in a population of healthy Western Canadians. CMAJ 2002;166:1517.

63 McKenna MJ, Murray BF, O'Keane M, et al. Rising trend in vitamin D status from 1993 to 2013: dual concerns for the future. Endocr Connect 2015;4:163-71.

64 Australian Bureau of Statistics. National health survey: first results, 2017-18, 2018. Available: https://www.abs.gov.au/ausstats/abs@. $\mathrm{nsf} / \mathrm{mf} / 4364.0 .55 .001$ [Accessed 12 Dec 2019].

65 Beketova NA, Pavlovskaya EV, Kodentsova VM, et al. [Biomarkers of vitamin status in obese school children]. Vopr Pitan 2019;88:66-74.

66 Orces $\mathrm{C}$. The association between body mass index and vitamin D supplement use among adults in the United States. Cureus 2019;11:e5721.

67 Li J, Gao Y, Yu T, et al. Obesity and leptin influence vitamin D metabolism and action in human marrow stromal cells. J Steroid Biochem Mol Biol 2019;198:105564.

68 Vanlint S. Vitamin D and obesity. Nutrients 2013;5:949-56. 